\title{
Optimising nitrogen in order to improve the efficiency, eco-physiology, yield and quality on one cultivar of durum wheat
}

\author{
Luigi Tedone, Leonardo Verdini, Nicola Grassano, Waed Tarraf, Giuseppe De Mastro \\ Department of Agricultural and Environmental Science, University Aldo Moro of Bari, Italy
}

\begin{abstract}
A 3-year field experiment was carried out in southern Italy to evaluate the effect of different combinations of nitrogen $(\mathrm{N})$ fertiliser rates $\left(0,55,90,135 \mathrm{~kg} \mathrm{ha}^{-1}\right)$, time of application (sowing, tillering, stem elongation) and number of nitrogen applications on durum wheat (Triticum turgidum L., var. durum). A total of eight different combinations - in terms of quantity and time of application - were arranged in a randomized complete block design with four replications. Soil plant analysis development was analysed along with leaf area index, grain and straw yield, plant height, plant lodging, thousand-kernel weight, non-vitreous kernels, shrunken and discarded kernels, hectolitre weight, grain protein content, and sodium dodecylsulfate sedimentation. Nitrogen contents of soil, grain and straw were measured in order to assess nitrogen efficiency. The results showed the positive effect of increased nitrogen dosages of 90 and $135 \mathrm{~kg} \mathrm{ha}^{-1}$. The optimisation of nitrogen administration increased by splitting the nitrogen into three application times, as shown by the eco-physiological, productive and qualitative parameters, and the nitrogen efficiency parameters measured ( $\mathrm{N}$ application efficiency and $\mathrm{N}$ recovery fraction).
\end{abstract}

Correspondence: Luigi Tedone, Department of Agricultural and Environmental Science, University Aldo Moro of Bari, via Orabona 4, 70126 Bari, Italy.

Tel. +39.080.5442501.

E-mail: luigi.tedone@uniba.it

Key words: durum wheat, nitrogen application, yield, grain quality, nitrogen efficiency.

Conference presentation: SIA XLI Congress, Bari, 2012.

Received for publication: 10 June 2013.

Revision received: 12 February 2014.

Accepted for publication: 15 February 2014.

(C) Copyright L. Tedone et al., 2014

Licensee PAGEPress, Italy

Italian Journal of Agronomy 2014; 9:536

doi:10.4081/ija.2014.536

This article is distributed under the terms of the Creative Commons Attribution Noncommercial License (by-nc 3.0) which permits any noncommercial use, distribution, and reproduction in any medium, provided the original author(s) and source are credited.

\section{Introduction}

Durum wheat (Triticum turgidum L. subsp. durum) is the most cultivated autumn-sown crop in southern Italy in rainfed conditions. In 2012 about 1.3 million hectares were sown in Italy, of which approximately 274,700 ha were in Apulia, one of the southern most important regions (National Institute of Statistics, 2012). Wheat is primarily cultivated for pasta production and bread, the main foods for the traditional Italian diet. Although Italy is the largest world producer of durum wheat, demand outweighs supply, thus medium-high quality grain has to be imported (Flagella, 2006). Climate, soil type (Karlen et al., 2008) and agronomic practices are well known to influence grain yield and quality. Air temperature and seasonal trends during grain filling and ripening, strongly affect yield and quality (Dalla Marta et al., 2011).

Nitrogen (N) supply in combination with climatic conditions are the main constraints to the physiological component, yield potential, and qualitative parameters of wheat (Garabet et al., 1998).

The response of wheat to $\mathrm{N}$ fertiliser is influenced by the formulation, fertiliser management, soil property, crop sequence, seasonal trends, and the supply of residual and mineralised $\mathrm{N}$ (Bonciarelli and Ciriciofolo, 2001; Campbell et al., 1993; Huggins and Pan, 1993; Borghi et al., 1997; Desiderio et al., 1998).

López-Bellido et al. $(2000,2001,2012)$ showed that in Mediterranean conditions, the application of $\mathrm{N}$ during the sowingstem elongation period gives the best results in terms of grain yield in dry years, while the application of nitrogen during tillering-stem elongation results in significant grain yields in wet years. In any case, how the fertiliser responds depends on the previous crop in the rotation, and the amount of residual $\mathrm{N}$ in the soil at the end of winter. In addition, water stress during the grain filling period, greatly reduces the $\mathrm{N}$ and dry matter accumulation in durum wheat (Ercoli et al., 2009).

Fertilisation management in terms of fertiliser rate and application timing aims to prevent $\mathrm{N}$ deficiency in critical periods in terms of yield and/or protein accumulation so that leaching and gaseous emissions are minimised. Some studies have shown that, depending on the level of fertility of the initial soil, split applications of $\mathrm{N}$ fertiliser result in higher rates of plant recovery and higher grain yields than under single applications (Mahler et al., 1994; Stockdale et al., 1997; Recous and Machet, 1998; Borghi, 2000; Blankenau et al., 2002).

The response of nitrogen in terms of time application to the protein content is rather different. Applying half or one-third of the $\mathrm{N}$ rate (150 $\mathrm{kg} \mathrm{N} \mathrm{ha}{ }^{-1}$ ) at a later stage (boot and head-emergence stage) can significantly enhance the amount of all protein fractions (Flagella, 2006; D'Egidio et al., 2000).

Splitting the amount of $\mathrm{N}$ fertiliser also increases the efficiency of nitrogen use efficiency, with a higher plant recovery of this mineral and an increase in grain yield and quality, compared to a single application (López-Bellido et al., 2012).

To match the nitrogen supply to the crop nitrogen demand, indices have been exploited to have an indication of chlorophyll content such as the normalised difference vegetation indices, the measure of canopy chlorophyll content through changes in reflectance patterns in 
the near-infrared, middle infrared reflectance (Rodriguez et al., 2005), soil plant analysis development (SPAD) or $\mathrm{N}$ testers (Arregui et al., 2006). Some indices have been developed using thermal images along with reflectance measurements, such as the canopy chlorophyll content index. The use of several models of nitrogen turnover in the soil-crop system has shown that $\mathrm{N}$ uptake by the crops and their production of dry matter were simulated very well in some cases and rather less so in others (Basso et al., 2009).

Appropriately managing $\mathrm{N}$ fertiliser for wheat production in dry areas is critical in obtaining the maximum economic yield, and for improving water efficiency. Good nitrogen management also makes good environmental sense. Excess fertiliser nitrogen applications increase environmental losses of nitrogen, including nitrate leaching to groundwater and emissions of nitrous oxide and greenhouse gases.

The objectives of this work were to investigate the effects of different nitrogen fertiliser application models on the physiology, productive and qualitative parameters of durum wheat cultivated in a Mediterranean climate. We also analysed its efficiency.

\section{Materials and methods}

\section{Site}

A field experiment was carried out in Gravina in Apulia, southern Italy $\left(40^{\circ} 53^{\prime} \mathrm{N}, 16^{\circ} 17^{\prime} \mathrm{E}, 456 \mathrm{~m}\right.$ asl), for three years $(2008-2011)$ to investigate the effects of nitrogen levels and time of applications on growth, yield and grain quality on a variety of durum wheat (Triticum turgidum L., var. durum). The site is typical of a semi-arid Mediterranean climate according to de Martonne's extended classification, with an average annual rainfall of $450 \mathrm{~mm}$ concentrated mainly during October-May, and with an average annual temperature of $13.5^{\circ} \mathrm{C}$.

The data were obtained from agro-meteorological data provided by the regional government in Apulia (ASSOCOPUGLIA).

\section{Crop management}

The durum wheat cultivar grown was Iride. The cultivar shows an early cycle and medium-to-low height, and is characterized by high productivity and adaptability, while the quality of semolina presents low content of proteins (CRA-QCE, 2012).

The experiment was performed in the same field every year. Phosphorus (P) was applied in the form of triple superphosphate $(45 \%$ $\mathrm{N}$ ) at dose of $46 \mathrm{~kg} \mathrm{ha}^{-1}$ of $\mathrm{P}_{2} \mathrm{O}_{5}$. Potassium (K) supply from the soil was adequate $\left(674.9 \mathrm{mg} \mathrm{kg}^{-1}\right)$. Nitrogen was applied at the rates of: 0,55 , 90 and $135 \mathrm{~kg} \mathrm{ha}^{-1}$.

In all the three years, the crop was sown, in the second half of November, at a seeding rate designed to obtain 400 germinating seeds $\mathrm{m}^{-2}$ (200 kg ha ${ }^{-1}$ of seed), using a common seeder $18 \mathrm{~cm}$ wide rows.

For weed control, pinoxaden $9.51 \%\left(100 \mathrm{gL}^{-1}\right)$, cloquintocet-mexyl 2.38\% (25 $\left.\mathrm{gL}^{-1}\right)$, clodinafop-propargyl 9.51\% $\left(100 \mathrm{gL}^{-1}\right)$ were applied at the end of tillering $\left(0.25 \mathrm{~L} \mathrm{ha}^{-1}\right)$.

The harvest was carried out at the end of June, using a $1.5 \mathrm{~m}$ wide Wintersteiger plot combine harvester (Wintersteiger Inc., Salt lake City, UT, USA).

\section{Experimental design}

A randomized complete block design was used with four replications. Each nitrogen treatment involved a combination of three application times (sowing, tillering and stem elongation) and different doses.

At sowing time $0.0,18.0$ and $40.0 \mathrm{~kg} \mathrm{ha}^{-1}$ were applied, at tillering
0.0, 18.5, 37.0, 50.0, 58.5, 72.0, 90.0 and $117.0 \mathrm{~kg} \mathrm{ha}^{-1}$, and at the stem elongation $0.0,18.5,36.0$ and $58.5 \mathrm{~kg} \mathrm{ha}^{-1}$. Ammonium was used during sowing, tillering, and ammonium nitrate at the stem elongation. In total the following eight combinations were compared (the first number is the dose in $\mathrm{kg} \mathrm{ha}^{-1}$ of nitrogen applied at sowing time, the second at tillering, the third at stem elongation): $0-0-0,18-37-0,18-18.5$ $18.5,0-90-0,40-50-0,18-72-0,18-36-36,18-117-0$, and 18-58.5-58.5.

The individual gross size of the plot was $72 \mathrm{~m}^{2}(7.2 \times 10.0 \mathrm{~m})$, whereas the net harvested size was $36 \mathrm{~m}^{2}(4.5 \times 8.0 \mathrm{~m})$.

\section{Soil analysis}

Before starting the experiment, a soil sampling was effectuated to evaluate the characteristic of the soil. The soil analysis were effected according the Italian Regulation (1999), and present the following results: sand $(2>\emptyset>0.02 \mathrm{~mm}) 36.0 \%$, silt $40.1 \%$, clay $(\emptyset<2 \mathrm{~mm}) 23.9 \%$; pH 7.7; total $\mathrm{N} 1.1 \mathrm{~g} \mathrm{~kg}^{-1}$, available $\mathrm{P}_{2} \mathrm{O}_{5}$ (Olsen method) $64.3 \mathrm{mg} \mathrm{kg}^{-1}$, exchangeable $\mathrm{K}_{2} \mathrm{O}$ (ammonium acetate method) $674.9 \mathrm{mg} \mathrm{kg}^{-1}$, organic matter $2.2 \%$.

\section{Soil nitrogen monitoring}

During each year of experiment, soil samples were collected prior to sowing and after harvesting the wheat from each plot, to a depth of 0 $50 \mathrm{~cm}$.

\section{Ecophysiological determinations}

Growth parameters measured included: flag leaf area, heading, duration of grain filling and plant height (Zadoks et al., 1974).

To evaluate the nutritional status of the plants, non-destructive determinations during growth were performed: i) leaf greenness determination using a SPAD-502 ${ }^{\circledR}$ chlorophyll meter (Konica Minolta Inc., Tokyo, Japan). Readings with the chlorophyll meter were carried out when the flag leaf stage was just visible (GS-3.7); ii) leaf area index (LAI) determination of the canopy on cloudless days in the booting phase (GS 4.0) measured with a Linear PAR Ceptometer (AccuPAR, Decagon Devices Inc., Pullman, WA, USA).

\section{Yield and qualitative determination}

Before harvest, the height, density and plant lodging were recorded.

Number of spikes per $\mathrm{m}^{2}$, total biomass $\left(\mathrm{t} \mathrm{ha}^{-1}\right)$, grain and straw yield $\left(\mathrm{t} \mathrm{ha}^{-1}\right)$ were measured at harvest time.

Harvest index, hectolitre weight $(\mathrm{kg} / \mathrm{hL}), 1000$ seed weight $(\mathrm{g})$, nonvitreous kernels (\%), gluten content (Italian Regulation, 1994), sodium dodecylsulfate sedimentation (SDS) (ICC 151-International Association for Cereal Science and Technology) values were determined for each treatment and replication.

Straw and grain total nitrogen content (Kjeldhal method) was analysed in accordance with the main objectives of the study.

\section{Nitrogen efficiency}

The following N-efficiency parameters were calculated for each treatment (López-Bellido et al., 2005):

- $\mathrm{N}$ utilisation efficiency (NUtE; $\mathrm{kg} \mathrm{kg}^{-1}$ ) - ratio of grain yield to total plant $\mathrm{N}$ uptake;

- $\mathrm{N}$ harvest index (NHI; \%) - ratio of $\mathrm{N}$ in grain to total plant $\mathrm{N}$ uptake; - N physiological efficiency (NPE; $\mathrm{kg} \mathrm{kg}^{-1}$ ) - ratio of (yield at $\mathrm{N}_{\mathrm{x}}$-yield at $\mathrm{N}_{0}$ ) to ( $\mathrm{N}$ uptake at $\mathrm{N}_{\mathrm{x}}-\mathrm{N}$ uptake at $\mathrm{N}_{0}$ );

$\mathrm{N}$ agronomic efficiency (NAE, $\mathrm{kg} \mathrm{kg}^{-1}$ ) - ratio of (yield at $\mathrm{N}_{\mathrm{x}}$-yield at $\mathrm{N}_{0}$ ) to applied $\mathrm{N}$ at $\mathrm{N}_{\mathrm{x}}$;

- N apparent recovery fraction (NRF; \%) - ratio of (N uptake at $\mathrm{N}_{\mathrm{x}}-\mathrm{N}$ uptake at $\mathrm{N}_{0}$ ) to applied $\mathrm{N}$ at $\mathrm{N}_{\mathrm{x}}$. 


\section{Statistical analysis}

All the data were submitted to analysis of variance (ANOVA), using a year-combined randomised complete block design (Table 1). Treatment means were compared using the Student Newman Keuls test at $\mathrm{P} \leq 0.05$ with CoStat software.

\section{Results}

\section{Weather conditions}

At the experimental site the rainfall trend varied considerably during the three-year period (Figure 1). In 2008-2009 there was a total rainfall of $832 \mathrm{~mm}$, mainly concentrated in November-January, with an high amount of precipitation during the months of April and May, and with excess of rain at harvest time (June).

In the second year (2009-2010) the total rainfall was of $713 \mathrm{~mm}$, well distributed during the wheat-growing period, and with a higher monthly value than the pluriannual mean of the area (Figure 1).

The wettest year was 2010-2011 with $869 \mathrm{~mm}$. The amount of precipitation during March and April, caused a high incidence of pathological problems in the vegetation. On the basis of the pluriannual (means of 30 years) rainfall data, all the three-years were wetter than normal, showing a 15-35\% increasing. Mean winter temperature values ranged between 1.5 and $13.3^{\circ} \mathrm{C}$. The minimum winter temperature ranged from $-2.3^{\circ} \mathrm{C}$ to $6.8^{\circ} \mathrm{C}$ for the three year, from -2.1 to $5.5^{\circ} \mathrm{C}$ for $2008-2009$, from -0.3 to $6.8^{\circ} \mathrm{C}$ for $2009-2010$ and from -2.3 to $6.4^{\circ} \mathrm{C}$ for $2010-2011$.

Table 1. Efficiency measurements of nitrogen parameters for durum wheat by year and timing of nitrogen dose.

\begin{tabular}{|c|c|c|c|c|c|}
\hline Treatments & NUtE $\left(\mathrm{kg} \mathrm{kg}^{-1}\right)$ & NHI (\%) & NPE $\left(\mathrm{kg} \mathrm{kg}^{-1}\right)$ & $\operatorname{NAE}\left(\mathrm{kg} \mathrm{kg}^{-1}\right)$ & NRF $(\%)$ \\
\hline $\begin{array}{l}\text { Year } \\
2009 \\
2010 \\
2011\end{array}$ & $\begin{array}{l}53.7^{\mathrm{a}} \\
50.8^{\mathrm{b}} \\
50.0^{\mathrm{b}}\end{array}$ & $\begin{array}{l}86.3^{\mathrm{a}} \\
84.9^{\mathrm{b}} \\
82.4^{\mathrm{c}}\end{array}$ & $\begin{array}{l}41.8^{\mathrm{a}} \\
51.5^{\mathrm{a}} \\
46.5^{\mathrm{a}}\end{array}$ & $\begin{array}{c}7.3^{\mathrm{b}} \\
17.4^{\mathrm{a}} \\
16.4^{\mathrm{a}}\end{array}$ & $\begin{array}{l}20.8^{\mathrm{b}} \\
35.2^{\mathrm{a}} \\
35.3^{\mathrm{a}}\end{array}$ \\
\hline $\begin{array}{l}\text { N treatment } \\
0-0-0 \\
18-37-0 \\
18-18.5-18.5 \\
0-90-0 \\
40-50-0 \\
18-72-0 \\
18-36-36 \\
18-117-0 \\
18-58.5-58.5 \\
\end{array}$ & $\begin{array}{c}55.7^{\mathrm{a}} \\
53.8^{\mathrm{a}} \\
53.4^{\mathrm{a}} \\
53.8^{\mathrm{a}} \\
50.7^{\mathrm{ab}} \\
51.7^{\mathrm{ab}} \\
51.5^{\mathrm{ab}} \\
48.0^{\mathrm{b}} \\
49.5^{\mathrm{ab}}\end{array}$ & $\begin{array}{l}86.0^{0^{a b}} \\
87.2^{\mathrm{a}} \\
85.2^{\mathrm{b}} \\
84.6^{\mathrm{b}} \\
85.0^{\mathrm{b}} \\
84.9^{\mathrm{b}} \\
85.6^{\mathrm{b}} \\
79.6^{\mathrm{d}} \\
82.8^{\mathrm{c}}\end{array}$ & $\begin{array}{l}55.3^{\mathrm{a}} \\
58.6^{\mathrm{a}} \\
59.2^{\mathrm{a}} \\
43.5^{\mathrm{a}} \\
48.1^{\mathrm{a}} \\
45.8^{\mathrm{a}} \\
40.5^{\mathrm{a}} \\
35.3^{\mathrm{a}}\end{array}$ & $\begin{array}{c}16.2^{\mathrm{ab}} \\
19.6^{\mathrm{a}} \\
13.0^{\mathrm{b}} \\
7.6^{\mathrm{c}} \\
13.9^{\mathrm{b}} \\
18.8^{\mathrm{a}} \\
11.5^{\mathrm{b}} \\
12.7^{\mathrm{b}}\end{array}$ & $\begin{array}{c}29.8^{\mathrm{ab}} \\
37.2^{\mathrm{a}} \\
24.3^{\mathrm{ab}} \\
20.7^{\mathrm{b}} \\
30.6^{\mathrm{ab}} \\
39.9^{\mathrm{a}} \\
29.5^{\mathrm{ab}} \\
31.5^{\mathrm{ab}}\end{array}$ \\
\hline Means & 51.5 & 84.6 & 46.6 & 13.7 & 30.4 \\
\hline
\end{tabular}

$\mathrm{N}$, nitrogen; NutE, N utilisation efficiency; NHI, $\mathrm{N}$ harvest index; NPE, N physiological efficiency; NAE, N agronomic efficiency; NRF, N apparent recovery fraction. a,b,c,dFor each year and effect, means followed by the same letter are not significantly different at $\mathrm{P} \leq 0.05$ according to Student Newman Keuls test.
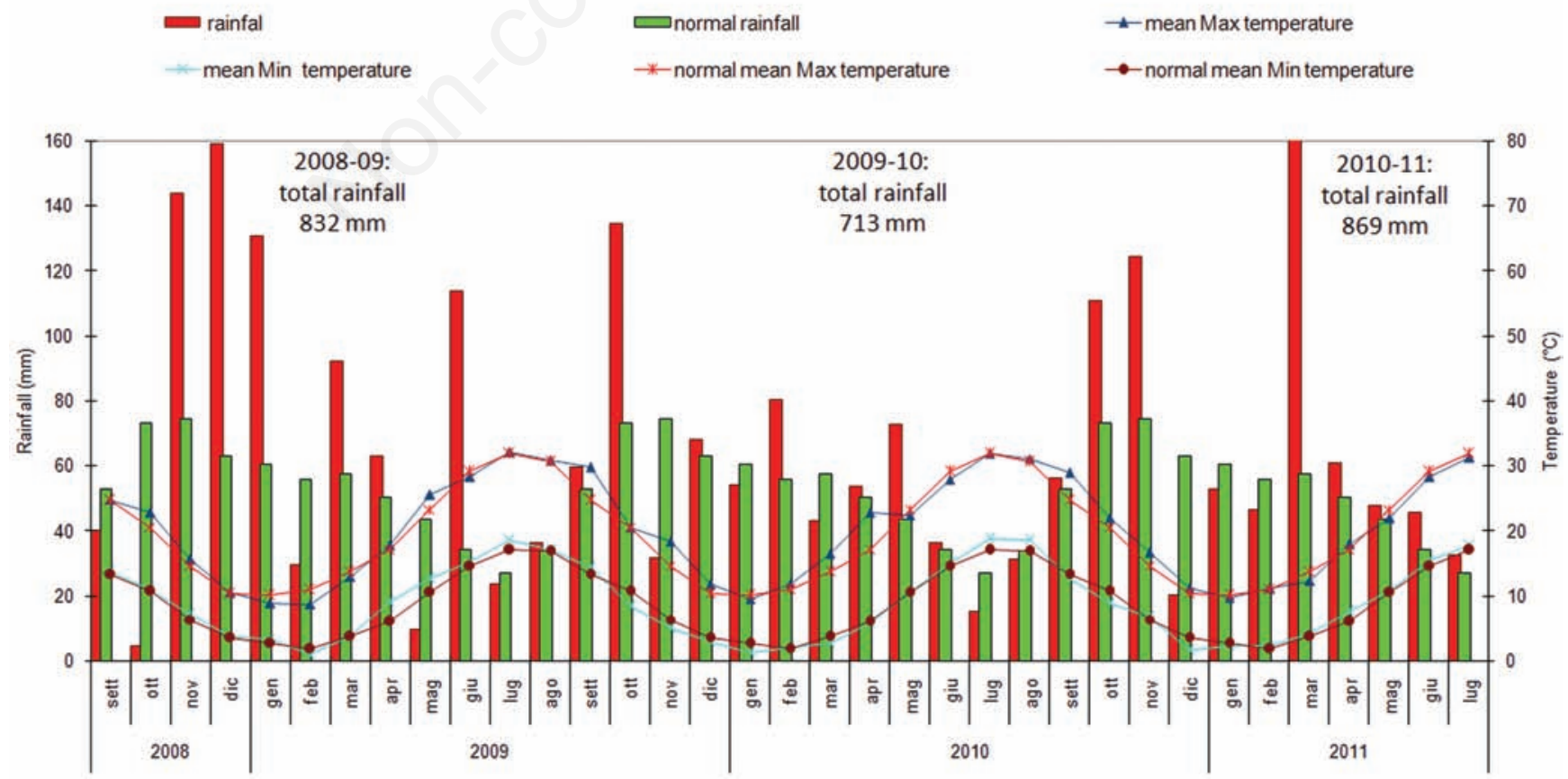

Figure 1. Monthly and annual rainfall, maximum, minimum and mean temperatures over the 3-year case study. 
During grain filling (April-May), the mean temperature of the three years was $15.3^{\circ} \mathrm{C}$, the minimum reached values between 9.0 and $12.6^{\circ} \mathrm{C}$ in 2008-2009, between 6.5 and $13.1^{\circ} \mathrm{C}$ in $2009-2010$, and between 5.2 and $14.5^{\circ} \mathrm{C}$ for $2010-2011$. The maximum temperature during this period ranged between 16.5 to $29.3^{\circ} \mathrm{C}$ for $2008-2009$, between 19.2 and $25.8^{\circ} \mathrm{C}$ for $2009-2010$, between 15.6 to $26.1^{\circ} \mathrm{C}$ for $2010-2011$.

In total, the 2009-2010 was the most favourable year for cultivation, which led to a good cultivation and better average grain yield.

\section{Physiological component}

The highest SPAD (49.1) and LAI max (6.16) values were measured in the treatment with the highest amount of nitrogen: $135 \mathrm{~kg} \mathrm{ha}^{-1}$, in particular when the nitrogen was applied during the vegetative phases (18-117-0), confirming the findings of other papers (Flagella, 2006).

Other high values were measured when the nitrogen was split into three administration times (Table 2). Infact the physiological measurements of the crop, when the application was split during the three phases, confirm the better nutritional status of the cultivation during the crop cycle (López-Bellido, 2012).

\section{Yield components}

The effect of the weather condition on the main yield components measured was very significant.

The number of heads $\mathrm{m}^{-2}$ was significantly higher in the second year ( 533 heads $\mathrm{m}^{-2}$ ), compared to the first and third years.

The best yield performance was in 2008-2009 with the highest yield grain (5.3 $\left.\mathrm{t} \mathrm{ha}^{-1}\right)$, thousand seed weight (42.9 g), plant height (86.7 $\mathrm{cm}$ ) and harvest index (HI) (0.44). As a consequence, there was a negative effect on the qualitative parameters: grain protein (11.7\%), and SDS (51 mL).

In the second year there was an increase in grain protein and SDS and a slight decrease in yield $\left(4.6 \mathrm{t} \mathrm{ha}^{-1}\right)$. The grain protein and $\mathrm{HI}$ were the highest (12.2\% and $46 \%)$; the non-vitreous kernel percentage was the lowest (37\%).

Nitrogen positively affected the heads $\mathrm{m}^{-2}$ that significantly increased in all the treatments (between 454 to 506 heads $\mathrm{m}^{-2}$ ) compared to the treatment without nitrogen (416 heads $\mathrm{m}^{-2}$ ). Also plant height significantly increased with $\mathrm{N}$ treatment $0-0-0(76.2 \mathrm{~cm})$ compared to the other treatments (values included between $80.9 \mathrm{~cm}$ to $83.6 \mathrm{~cm}$ ).

The highest grain yields $\left(4.8 \mathrm{t} \mathrm{ha}^{-1}\right)$ were recorded with nitrogen doses of 90 (18-36-36) and 135 (18-58.5-58.5) kg ha-1, although no significant difference was observed for the other treatments (Table 3 ).

These results confirm the data recorded for the physiological parameters, where low applications of nitrogen until stem elongation also produced the best results in terms of crop development (SPAD-LAI) and consequent yield.

The best grain yield was recorded with the application of 90 (18-36$36)$ and 135 (18-58.5-58.5) $\mathrm{kg} \mathrm{ha}^{-1}$ applied in the three phases are supported by the other values such as: heads, respectively 506 and $490 \mathrm{~h}$ $\mathrm{m}^{-2}$, thousand seed weight ( $42.4 \mathrm{~g}$ and $42.8 \mathrm{~g}$ ) and discarded and broken kernels (1.5\% and 1.6\%), non vitreous kernels (44.3\% and 35.8\%), hectolitre weight (77.9 and $78 \mathrm{~kg} \mathrm{hL}^{-1}$ ), grain protein content (12.0 and

Table 2. Soil plant analysis development and leaf area index max values in the nitrogen treatments.

\begin{tabular}{lcc} 
Treatment & SPAD & LAI \\
$0-0-0$ & $37.5^{\mathrm{c}}$ & $3.69^{\mathrm{c}}$ \\
$18-37-0$ & $43.8^{\mathrm{abc}}$ & $5.23^{\mathrm{ab}}$ \\
\hline $18-18.5-18.5$ & $47.9^{\mathrm{ab}}$ & $5.55^{\mathrm{a}}$ \\
$0-90-0$ & $43.7^{\mathrm{abc}}$ & $3.97^{\mathrm{bc}}$ \\
\hline $40-50-0$ & $41.5^{\mathrm{bc}}$ & $5.44^{\mathrm{ab}}$ \\
$18-72-0$ & $47.5^{\mathrm{ab}}$ & $5.31^{\mathrm{ab}}$ \\
\hline $18-36-36$ & $47.5^{\mathrm{ab}}$ & $5.72^{\mathrm{a}}$ \\
$18-117-0$ & $49.1^{\mathrm{a}}$ & $6.16^{\mathrm{a}}$ \\
\hline $18-58.5-58.5$ & $47.2^{\mathrm{ab}}$ & $5.73^{\mathrm{a}}$ \\
Mean & 45.1 & 5.2 \\
\hline SPAD, soil plant analysis development; LAI, leaf area index. ab,c, Data followed by the same letter, in \\
each column, are not significantly different at P $\leq 0.05$ according to the Student Newman Keuls test.
\end{tabular}

Table 3. Biometric, productive and qualitative results in the wheat affected by different nitrogen applications.

\begin{tabular}{|c|c|c|c|c|c|c|c|c|c|c|}
\hline Treatments & $\begin{array}{c}\text { Heads } \\
\left(\mathrm{h} \mathrm{m}^{-2}\right) \\
(\mathrm{cm})\end{array}$ & $\begin{array}{l}\text { Height } \\
\text { plant } \\
\left(\mathrm{t} \mathrm{ha}^{-1}\right)\end{array}$ & $\begin{array}{l}\text { Grain } \\
\text { yield }\end{array}$ & $\begin{array}{l}\text { Harvest } \\
\text { index } \\
\text { (g) }\end{array}$ & $\begin{array}{l}\text { Thousand } \\
\text { seed weight } \\
(\%)\end{array}$ & $\begin{array}{c}\text { Non-vitreous } \\
\text { kernels } \\
\text { kernels } \\
(\%)\end{array}$ & $\begin{array}{c}\text { Shrunken } \\
\text { and } \\
\text { broken }\end{array}$ & $\begin{array}{c}\text { SDS } \\
(\mathrm{mL}) \\
(\mathrm{kg} / \mathrm{hL})\end{array}$ & $\begin{array}{c}\text { Hectolitre } \\
\text { weight }\end{array}$ & $\begin{array}{l}\text { Grain protein } \\
\text { content }(\%)\end{array}$ \\
\hline \multicolumn{11}{|l|}{ Year } \\
\hline 2009 & $433^{b}$ & $86.7^{\mathrm{a}}$ & $5.3^{\mathrm{a}}$ & $0.44^{b}$ & $42.9^{\mathrm{a}}$ & $77.0^{\mathrm{a}}$ & 2.4 & 51 & $77.3^{\mathrm{b}}$ & $11.7^{\mathrm{b}}$ \\
\hline 2010 & $511^{\mathrm{a}}$ & $81.4^{b}$ & $4.6^{\mathrm{b}}$ & $0.46^{\mathrm{a}}$ & $41.8^{a b}$ & $37.1^{\mathrm{b}}$ & 1.1 & 52 & $77.9^{\mathrm{ab}}$ & $12.2^{\mathrm{a}}$ \\
\hline 2011 & $461^{b}$ & $76.1^{\mathrm{c}}$ & $2.7^{c}$ & $0.46^{\mathrm{a}}$ & $41.2^{\mathrm{b}}$ & $44.8^{b}$ & 2.0 & 52 & $80.0^{\mathrm{a}}$ & $12.0^{a b}$ \\
\hline \multicolumn{11}{|l|}{$\mathrm{N}$ treatment } \\
\hline $0-0-0$ & $416^{b}$ & $76.2^{\mathrm{b}}$ & $3.1^{\mathrm{c}}$ & $0.46^{\mathrm{ab}}$ & $42.4^{\mathrm{a}}$ & $76.2^{\mathrm{a}}$ & 1.8 & $49^{b c}$ & $78.5^{\mathrm{a}}$ & $11.2^{\mathrm{c}}$ \\
\hline $18-37-0$ & $479^{\mathrm{ab}}$ & $80.9^{\mathrm{a}}$ & $4.0^{\mathrm{ab}}$ & $0.47^{\mathrm{a}}$ & $42.0^{\mathrm{a}}$ & $61.1^{\mathrm{ab}}$ & 1.8 & $49^{b c}$ & $77.3^{\mathrm{ab}}$ & $11.7^{b c}$ \\
\hline $18-18.5-18.5$ & $466^{\mathrm{ab}}$ & $81.5^{\mathrm{a}}$ & $4.3^{\mathrm{ab}}$ & $0.44^{c}$ & $42.6^{\mathrm{a}}$ & $49.9 c$ & 1.9 & $52^{\mathrm{ab}}$ & $78.6^{\mathrm{a}}$ & $11.9^{\mathrm{ab}}$ \\
\hline $0-90-0$ & $454^{\mathrm{ab}}$ & $81.4^{\mathrm{a}}$ & $4.0^{\mathrm{ab}}$ & $0.45^{b c}$ & $42.4^{\mathrm{a}}$ & $50.0^{\mathrm{bc}}$ & 1.8 & $56^{\mathrm{a}}$ & $77.7^{\mathrm{ab}}$ & $11.8^{b c}$ \\
\hline $40-50-0$ & $462^{a b}$ & $81.4^{\mathrm{a}}$ & $3.8^{\mathrm{bc}}$ & $0.46^{\mathrm{abc}}$ & $41.5^{\mathrm{a}}$ & $68.3^{\mathrm{a}}$ & 2.1 & $47^{c}$ & $77.1^{\mathrm{b}}$ & $12.2^{\mathrm{ab}}$ \\
\hline $18-72-0$ & $481^{a b}$ & $82.6^{\mathrm{a}}$ & $4.4^{\mathrm{ab}}$ & $0.44^{c}$ & $42.1^{\mathrm{a}}$ & $49.4^{b c}$ & 1.7 & $53^{\mathrm{ab}}$ & $77.3^{\mathrm{ab}}$ & $12.0^{\mathrm{ab}}$ \\
\hline $18-36-36$ & $506^{\mathrm{a}}$ & $82.5^{\mathrm{a}}$ & $4.8^{\mathrm{a}}$ & $0.47^{\mathrm{a}}$ & $42.4^{\mathrm{a}}$ & $44.3^{c}$ & 1.5 & $53^{\mathrm{ab}}$ & $77.9^{\mathrm{ab}}$ & $12.0^{\mathrm{ab}}$ \\
\hline $18-117-0$ & $478^{a b}$ & $83.6^{\mathrm{a}}$ & $4.7^{\mathrm{a}}$ & $0.46^{\mathrm{ab}}$ & $41.4^{\mathrm{a}}$ & $41.9 \mathrm{bc}$ & 2.4 & $57^{\mathrm{a}}$ & $77.4^{\mathrm{ab}}$ & $12.2^{\mathrm{ab}}$ \\
\hline $18-58.5-58.5$ & $490^{\mathrm{ab}}$ & $82.5^{\mathrm{a}}$ & $4.8^{a}$ & $0.46^{\mathrm{abc}}$ & $42.8^{\mathrm{a}}$ & $35.8^{\mathrm{c}}$ & 1.6 & $53^{\mathrm{ab}}$ & $78.0^{\mathrm{ab}}$ & $12.5^{\mathrm{a}}$ \\
\hline Mean & & 81.7 & 4.2 & 0.5 & 42.0 & 52.2 & 1.8 & 7.4 & 77.8 & 11.9 \\
\hline
\end{tabular}

SDS, sodium dodecylsulfate sedimentation; N, nitrogen. a,b,cFor each year and effect, means followed by the same letter are not significantly different at P $\leq 0.05$ according to Student Newman Keuls test. 
12.5\%). The data highlighted a positive effect of the nitrogen on protein content. In particular, with $90 \mathrm{~kg} \mathrm{ha}^{-1}$, the grain protein content ranged from 12.0 to $12.5 \%$.

Increasing nitrogen had a positive effect on protein content, while no administration in the final phase had a negative impact.

There was a similar trend for the percentage of non-vitreous kernels in the different treatments, due to the strict correlation with the grain protein content. The efficiency parameters of nitrogen were influenced by the year and also by the treatments: 2009 gave the highest value of NUtE (53.7 kg kg-1), NHI (86.3\%), while the value of NAE and NRF were the lowest ( $7.3 \mathrm{~kg} \mathrm{~kg}^{-1}$ and $20.8 \%$ respectively). Considering the data in terms of treatments, the highest value of NUtE was recorded when the application was included between 0 and $90 \mathrm{~kg} \mathrm{ha}^{-1}$. The measurements of $\mathrm{NHI}$ were also similar, with higher values in the treatments 18-37-0 and $0-0-0$, respectively $87.2 \%$ and $86.0 \%$. $\mathrm{N}$ agronomy efficiency was significantly influenced by the time of application. The highest values were recorded in the 18-18.5-18.5 and 18-58.5-58.5 treatments (respectively 19.6 and $18.8 \mathrm{~kg} \mathrm{~kg}^{-1}$ ), and the value increased when the applications were split into three different times. The apparent and recovery fraction of N, finally (NRF and NAE), was significantly affected by the grain splitting. The highest values were in fact measured in the 18-3636 (39.9\%) and 18-18.5-18.5 (37.2\%) treatments.

These latter data were directly related to grain yield and were significantly affected by $\mathrm{N}$ timing and splitting, while NAE increased when the nitrogen was applied at stem elongation, as also found by LópezBellido (2005).

\section{Discussion}

In line with other studies (Campbell et al., 1993; López-Bellido et al., 2012), a strong influence of climate was observed due to the particular high variability of rain during the growing season in the Mediterranean climate. The change in conditions caused the variations in physiological responses of the crop, grain yield and $\mathrm{N}$ efficiency.

In our study, the effect of nitrogen fertiliser in a modern durum wheat cultivar, confirms its importance in increasing grain yield compared to no $\mathrm{N}$ usage, as found from Ercoli et al. (2009). Nitrogen also leads to higher photosynthetic activity and canopy development, as shown by the SPAD and LAI values. This confirms the importance of $\mathrm{N}$ on the cultivation in different conditions typical of the Mediterranean climate (Ercoli et al., 2009; López-Bellido et al., 2012). The increase in application favoured an increase in yield in all cases in the three years, due to the higher average rain registered during the experiments. In this case, dry conditions were not verified, which in several experiments have resulted in a lower response of the nitrogen fertiliser (De Vita et al., 2007; López-Bellido et al., 2005). However, the rainy conditions result in pathological problems in the plant, causing the lower yield in 2012. The use efficiency (NUtE) values were in the range measured in modern durum wheat varieties in other experiments (Giambalvo et al., 2010). The seasonal trend of the three years, with higher values of rain, was favourable for the use of nitrogen, as found from López-Bellido (2012).

\section{Conclusions}

The application of $\mathrm{N}$ fertiliser on durum wheat crop confirms the importance of this nutrient in increasing production and improving the qualitative parameters of grain.
The study shows that, in southern of Italy, the application of $\mathrm{N}$ fertiliser rates could be optimised in terms of timing and splitting, in agreement with other studies (López-Bellido, 2005). In terms of the amount of nitrogen support, nitrogen applications between 90 and 135 $\mathrm{kg} \mathrm{ha}^{-1}$ appear to be the most effective doses, with a better response in terms of vegetation nutritional status and yield.

Splitting the application of nitrogen into three periods (sowing, tillering, stem elongation), appears more efficient than just one application, producing an increase of $15 \%$, or twice, where the increase is $7 \%$. This strategy appears to be effective in reducing the loss of soil nitrates, which is more dangerous during the winter period, as reported from several authors, due to the rainfall (López-Bellido, 2005). We found that $\mathrm{N}$ application efficiency and $\mathrm{N}$ recovery efficiency in wheat crops increased when $\mathrm{N}$ fertiliser is applied at the stem elongation phase, whereas high amounts of $\mathrm{N}$ at sowing time and tillering, resulted in poor efficiency.

The splitting the $\mathrm{N}$ dosage appears to prevent environmental problems connected with the potential $\mathrm{N}$ loss. However above all it could maximise the efficiency of wheat fertilization, thus increasing the yield in the Mediterranean region, and providing a rational management of wheat, which is the most widespread crop in Apulia Region.

\section{References}

Arregui LM, Lasa B, Lafarga A, Iraneta I, Baroja E, Quemadac M, 2006. Evaluation of chlorophyll meters as tools for $\mathrm{N}$ fertilization in winter wheat under humid Mediterranean conditions. Eur. J. Agron. 24:140-8.

Basso B, Cammarano D, Grace PR, Cafiero G, Sartori L, Pisante M, Landi G, De Franchi S, Basso F, 2009. Criteria for selecting optimal nitrogen fertiliser rates for precision agriculture. Ital. J. Agron. $4: 147-58$

Blankenau K, Olfs HW, Kuhlmann H, 2002. Strategies to improve the use efficiency of mineral fertiliser nitrogen applied to winter wheat. J. Agron. Crop. Sci. 188:146-54.

Bonciarelli U, Ciriciofolo E, 2001. Studio delle modifiche indotte da fattori agronomici sulla qualità del frumento duro. XXXIV Conv. SIA, Pisa, 2001. Felici Ed., Pisa, Italy, pp 149-50.

Borghi B, 2000. Nitrogen as determinant of wheat growth and yield. In: E.H. Satorre and G.A. Slafer (ed.) Wheat ecology and physiology of yield determination. Food Products Press, New York, USA, pp 67-84.

Borghi B, Corbellini M, Minoia C, Palumbo M, Di Fonzo N, Perenzin M, 1997. Effects of Mediterranean climate on wheat bread-making quality. Eur. J. Agron. 6:145-54.

Campbell CA, Zentner RP, Selles F, McConkey BG, Dyck FB, 1993. Nitrogen management for spring wheat grown annually on zerotillage: yield and nitrogen use efficiency. Agron. J. 85:107-14.

CRA-QCE, 2012. Le varietà di frumento duro in Italia. Risultati della rete nazionale di sperimentazione 1999-2012. Available from: http://qce.entecra.it/

Dalla Marta A, Grifoni D, Mancini M, Zipoli G, Orlandini S, 2011. The influence of climate on durum wheat quality in Tuscany, Central Italy. Int. J. Biometeorol. 55:87-96.

D’Egidio MG, Desiderio E, Cecchini C, Cantone MT, Dottori A, Brogna G, Fornara M, 2000. Fertilizzazione azotata e qualità del frumento duro. Molini d'Italia 8:39-44.

De Willigen P, 1991. Nitrogen turnover in the soil-crop system; comparison of fourteen simulation models. Fertil. Res. 27:141-9.

De Vita P, Di Paolo E, Fecondo G, Di Fonzo N, Pisante M, 2007. Notillage and conventional tillage effects on durum wheat yield, grain quality and soil moisture content in southern Italy. Soil Till. 
Res. 92:69-78.

Desiderio E, D’Egidio MG, Ciriciofolo E, Codoni D, Lendini M, Palumbo M, Porfiri 0, Fornara M, Cecchini C, 1998. Effetti della concimazione azotata su produzione e qualità della granella di frumento duro. Inf. Agr. 10:31-8.

Ercoli L, Masoni A, Mariotti M, Arduini I, 2009. Accumulation of dry matter and nitrogen in durum wheat during grain filling as affected by temperature and nitrogen rate. Ital. J. Agron. 1:3-13.

Flagella Z, 2006. Qualità nutrizionale e tecnologica del frumento duro. Ital. J. Agron. 1:203-39.

Garabet S, Ryan J, Wood M, 1998. Nitrogen and water effects on wheat yield in a Mediterranean-type climate. II. Fertilizer use efficiency with labeled nitrogen. Field Crops Res. 58:213-21.

Giambalvo D, Ruisi P, Di Miceli G, Frenda AS, Amato G, 2010. Nitrogen use efficiency and nitrogen fertilizer recovery of durum wheat genotypes as affected by interspecific competition. Agron. J. 102:707-15.

Huggins DR, Pan WL, 1993. Nitrogen efficiency component analysis: an evaluation of cropping system differences in productivity. Agron. J. 85:898-905.

Italian Regulation, 1994. Decreto Ministeriale 23 luglio 1994. Approvazione dei "Metodi ufficiali di analisi dei cereali e derivati Supplemento n. 4". In: Official Journal no. 186, 10/8/1994, S.0. no. 114. Available from: http://www.gazzettaufficiale.it/eli/id/1994/08/ 10/094A4960/sg;jsessionid=uCYrw9I9o7iQryamexZwuA_.ntc-as5guri2b

Italian Regulation, 1999. Decreto Ministeriale del 19 settembre 1999. Approvazione dei "Metodi Ufficiali di analisi di Chimica del suolo". In: Official Journal no. 248, 21/10/1999. Available from: http:// ctntes.arpa.piemonte.it/Bonifiche/Documenti/Norme/13_Set_99.pdf Karlen DL, Andrews SS, Wienhold BJ, Zobeck TM, 2008. Soil quality assessment: past, present and future. J. Integr. Biosci. 6:3-14.

López-Bellido L, Munoz-Romero V, Benítez-Vegaa J, Fernández-García P, Redondo R, López-Bellido RJ, 2012. Wheat response to nitrogen splitting applied to a Vertisols in different tillage systems and cropping rotations under typical Mediterranean climatic conditions. Eur. J. Agron. 43:24-32.

López-Bellido L, López-Bellido RJ, Castillo JE, López-Bellido FJ, 2000. Effects of tillage, crop rotation, and nitrogen fertilization on wheat under rainfed Mediterranean conditions. Agron. J. 92:1054-63.

López-Bellido L, López-Bellido RJ, Redondo R, 2005. Nitrogen efficiency in wheat under rainfed Mediterranean conditions as affected by split nitrogen application. Field Crops Res. 94:86-97.

López-Bellido RJ, López-Bellido L, 2001. Efficiency of nitrogen in wheat under Mediterranean conditions: effect of tillage, crop rotation and N fertilization. Field Crops Res. 71:31-46.

Mahler RL, Koehler FE, Lutcher LK, 1994. Nitrogen source, timing of application, and placement: effects on winter wheat production. Agron. J. 86:637-42.

National Institute of Statistics, 2012. Dati agricoltura e zootecnia. Available from: http://dati.istat.it/

Recous S, Machet JM, 1998. Short-term immobilization and crop uptake of fertilizer nitrogen applied to winter wheat: effect of date of application in sprint. Plant Soil 206:137-49.

Rodriguez D, Sadras V0, Christensen LK, Belford R, 2005. Spatial assessment of the physiological status of wheat crops as affected by water and nitrogen supply using infrared thermal imagery. Aust. J. Agric. Res. 56:983-93.

Stockdale EA, Gaunt JL, Vos J, 1997. Soil-plant nitrogen dynamics: what concepts are required? Eur. J. Agron. 7:145-59.

Zadoks JC, Chang TT, Konzak CF, 1974. A decimal code for the growth stages of cereals. Weed Res. 14:415-21. 